\title{
Body Weight, Cholesterol Changes and Sub-Chronic Toxicity of Mice Treated with An Emulsion Product Rich in $\beta$-Carotene
}

\author{
Bohari ${ }^{1}$, Fenny Dian Lestari ${ }^{1}$, Anton Rahmadi ${ }^{2,3}$ \\ ${ }^{1}$ Department of Chemistry, Faculty of Natural Sciences and Mathematics, Universitas Mulawarman, Samarinda, Indonesia \\ ${ }^{2}$ Department of Agricultural Products Technology, Faculty of Agriculture, Universitas Mulawarman, Samarinda, Indonesia \\ ${ }^{3}$ Center of Excellence for Drugs and Cosmetics from Tropical Rain Forest, Universitas Mulawarman, Samarinda, Indonesia
}

Background: One of the conditions for releasing standardized herbal medicines is the presence of pre-clinical testing that can be conducted with mice. Emulsion products with the main composition of pumpkin, red palm oil, and dragon fruit have high levels of $\beta$-carotene. The purpose of this study was to observe changes in weight, cholesterol, and sub-chronic toxicity from mice treated with emulsion products.

Materials and Methods: Mice observed consisted of 6 groups: (1) untreated control (given standard ration); (2) negative control (given standard ration and $2.8 \%(\mathrm{v} / \mathrm{b}$ ) egg yolk); ( 3 ) positive control (given standard ration and $0.4 \%$ ( $\mathrm{v} / \mathrm{b}$ ) $\beta$-carotene); (4) standard ration, $0.4 \%(\mathrm{v} / \mathrm{b}) \beta$-carotene and $2.8 \%(\mathrm{v} / \mathrm{b})$ egg yolk; (5) given a standard ration and $2 \%(\mathrm{v} / \mathrm{b})$ emulsion products; and (6) given a standard ration, $2 \%(\mathrm{v} / \mathrm{b})$ emulsion products and $2.8 \%(\mathrm{v} / \mathrm{b})$ egg yolk. Observations of sub-chronic toxicity were done by measuring creatinine levels, kidney weight, and visual observation of kidney swelling.

Results: The use of $\beta$-carotene-rich emulsions does not cause a decrease in the average weight of mice. In general, $\beta$-carotene and emulsion can overcome cholesterol increases on the $7^{\text {th }}$ day, but not for the $15^{\text {th }}$ day as a result of standard food intake. The increase in creatinine levels only occurs in mice treated with egg yolk control. The additional treatment of $\beta$-carotene and emulsion successfully prevents the increase in creatinine levels.

Conclusion: Emulsion products did not cause changes in weight, were able to reduce cholesterol levels in a limited manner and were not toxic to mice.

Keywords: cholesterol changes, sub-chronic toxicity, $\beta$-carotene, emulsion

\section{Introduction}

In developing food products containing high carotenoids, including $\beta$-carotene and lutein, the safety test of these products is needed. Early and clinical pre-clinical tests are carried out in stages to prove acute and sub-chronic toxicity. ${ }^{1}$ Claims for carotenoid influences are the ability to reduce cholesterol levels and control oxidative stress in diabetics. ${ }^{2}$ The emulsion products tested have been shown to contain $\beta$-carotene as much as $2000 \mathrm{ppm}$ through high performance liquid chromatography (HPLC) testing. ${ }^{3}$ The intended emulsion product is composed of pumpkin, red

Date of submission: April 12, 2019

Last Revised: May 15, 2019

Accepted for publication: May 20, 2019

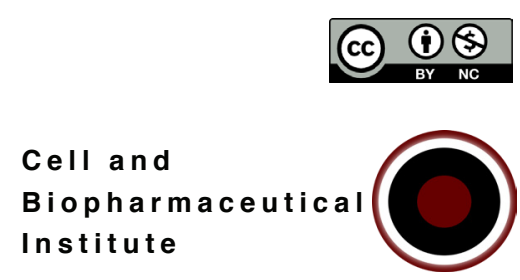

Corresponding Author:

Anton Rahmadi

Department of Agricultural Products Technology

Faculty of Agriculture, Universitas Mulawarman

Jl. Kuaro, Gn. Kelua, Samarinda 75119, Indonesia

e-mail: arahmadi@unmul.ac.id 
palm oil, and dragon fruit with a patent-protected formula composition no.: IDS000002040.

Mice are widely used as a pre-clinical model that can induce an increase in cholesterol levels through certain diets. ${ }^{4}$ To induce high cholesterol mice, egg yolks are used. Even though egg yolks contain carotene, the egg yolk diet causes an increase in high density lipoprotein (HDL) by as much as $17-25 \%$ of controls. ${ }^{5}$ In another study, increases in total cholesterol, HDL, triglycerides and free fatty acid (FFA) were observed from mice treated with serum from egg yolk. ${ }^{6}$ Hopefully, the addition of $2.8 \%$ (v/b) egg yolk treatment will increase the cholesterol level of mice. Prevention of an increase in total cholesterol is expected to be seen in groups of mice given additional treatment of $\beta$-carotene and emulsion.

Consumption of excessive egg yolk can cause inflammation in certain body parts. To prevent the possibility of inflammation in the body, carotenoid compounds are used as a counterweight to the egg yolk diet. ${ }^{7}$ The $\beta$-carotene compounds can inhibit the increase in blood cholesterol, mainly from the low density lipoprotein (LDL) group of mice given a high fat intake. ${ }^{8}$ Emulsion products have $\beta$-carotene levels of more than 2000 ppm. ${ }^{9}$ From the initial results, it was found that no mice died due to consumption of $0.4 \%$ $(\mathrm{v} / \mathrm{b}) \beta$-carotene and $2 \%(\mathrm{v} / \mathrm{b})$ emulsion products. Although long term effects of consuming any active substance is more accurately measured with cystatin-C, the quantification of such marker requires more advanced techniques i.e., enzyme-linked immunosorbent assay (ELISA) with specific enzyme that is reactive to mouse. This, however, cannot be performed in this research set up, therefore creatinine is used as the Jaffe reaction has less stringent requirement to be conducted. To find out the medium and long-term effects, sub-chronic testing can be accomplished by creatinine markers. ${ }^{10}$ In addition to observe the possibility of kidney swelling, weight and volume of kidneys were measured and compared to the control group.

This study aimed to determine changes in weight, cholesterol, and sub-chronic toxicity from mice treated with $\beta$-carotene and emulsion products with the main composition of pumpkin, red palm oil, and dragon fruit.

\section{Materials and methods}

\section{Raw Materials and Standard Solutions}

The raw material used in this study is emulsion products with the main composition of pumpkin, red palm oil, and dragon fruit (Patent No.: IDS000002040). The ingredients used for the analysis and toxicity test were $0.1 \mathrm{~N} \mathrm{KOH}$ (Merck, New Jersey, USA) dissolved in alcoholic solution, phenolphthalein (PP) indicator (Merck), aquadest, salt water, 95\% alcohol (Kimia Farma, Jakarta, Indonesia), activated carbon (AC) (Norit, Minato, Japan), diethyl ether (SigmaAldrich, Massachusetts, USA), Sensi ${ }^{\circledR}$ tissue pad alcohol, cholesterol strip (Easy Touch ${ }^{\circledR}$, Singapore, Singapore) (MHC Medical Products, Cincinnati, USA), lancet needle, creatinine kit (ReiGed Diagnostics, Jakarta, Indonesia). The ingredients used for mice rations are virgin coconut oil (VCO) (Al-Afiat, Magelang, Indonesia), $\beta$-carotene (SigmaAldrich), chicken egg yolk, hamsfood seeds (Hamsfood, Jakarta, Indonesia) (composition: carbohydrate 36.52\%, crude protein $13 \%$, crude fat $6 \%$, crude fiber $10 \%$, moisture $13 \%$, calcium $0.3 \%$, phosphor $0.2 \%$, salt $0.07 \%$, manganese $60 \mathrm{mg} / \mathrm{kg}$, zinc $50 \mathrm{mg} / \mathrm{kg}$, iron $65 \mathrm{mg} / \mathrm{kg}$, cooper $6.5 \mathrm{mg} / \mathrm{kg}$, iodine $0.7 \mathrm{mg} / \mathrm{kg}$, selenium $0.09 \mathrm{mg} / \mathrm{kg}$, vitamin A 24IU/kg, vitamin D 4 IU/kg, vitamin E 4 IU/kg, vitamin B1 $1.4 \mathrm{mcg} /$ $\mathrm{kg}$, vitamin B2 $1.2 \mathrm{mcg} / \mathrm{kg}$, vitamin B12 $1 \mathrm{mcg} / \mathrm{kg}$, inositol $3 \mathrm{mg} / \mathrm{kg}$, lysine $2 \mathrm{mg} / \mathrm{kg}$ ), consumable mineral water. Stock solution consists of: (1) $0.1 \mathrm{mg} \beta$-carotene $/ \mathrm{mL} \mathrm{VCO}$ solution, stored in the refrigerator, vortexed for 1 minute when used; (2) egg yolk solution as fat to induce cholesterol prepared fresh every day; (3) sample emulsion products are stored in the refrigerator, vortex for 1 minute when used. The test animals used were 2-3 months male Mus muculus mice with a body weight (BW) of $25 \pm 5 \mathrm{~g}$ originating from the Laboratory of Plant Pests and Diseases, Faculty of Agriculture, University of Mulawarman. Approval of animal ethics No. 29/KEPK-FK/III /2018 dated March 27, 2018 from the Faculty of Medicine, Universitas Mulawarman.

\section{Acclimatization and Description of Treatments}

In this study, male mice (Mus musculus) were used with an age of 2-3 months with a BW of $25 \pm 5 \mathrm{~g}$. Mice are maintained in cage made of plastic containers have been given a sand bed in controlled room temperature of $22 \pm 3{ }^{\circ} \mathrm{C}$ and a humidity range of $30-70 \%$.

The number of male mice to be used per treatment group was five. Mice are acclimatized for 7-14 days. During acclimatization, all groups were given a standard ration in the form of hamsfood grains and given water in ad libitum. ${ }^{11}$

Based on acclimatization data, one mouse consumed hamsfood about $10 \% \mathrm{~g} \mathrm{BW} /$ day. In the test, there were 6 different ration treatment groups as shown in Table 1. This study was carried out for 15 days after the mice were 
Table 1. Individual consumption in treatment groups.

\begin{tabular}{|c|c|c|c|c|c|c|}
\hline \multirow{2}{*}{ Ration } & \multicolumn{6}{|c|}{ Individual Cons umption in Treatment Group } \\
\hline & 1 & 2 & 3 & 4 & 5 & 6 \\
\hline Water & ad libitum & ad libitum & ad libitum & ad libitum & ad libitum & ad libitum \\
\hline Standard ration & $3 \mathrm{~g} \pm 5 \%$ & $3 \mathrm{~g} \pm 5 \%$ & $3 \mathrm{~g} \pm 5 \%$ & $3 \mathrm{~g} \pm 5 \%$ & $3 \mathrm{~g} \pm 5 \%$ & $3 \mathrm{~g} \pm 5 \%$ \\
\hline Egg yolk & & $0.7 \mathrm{~mL}$ & & $0.7 \mathrm{~mL}$ & & $0.7 \mathrm{~mL}$ \\
\hline $\begin{array}{l}\text { Pure } \beta \text {-carotene } \\
(0.1 \mathrm{mg} / \mathrm{mL} \text { in } \mathrm{VCO})\end{array}$ & & & $0.1 \mathrm{~mL}$ & $0.1 \mathrm{~mL}$ & & \\
\hline $\begin{array}{l}\text { Emulsion } \\
(>2000 \mathrm{ppm} \beta \text {-carotene })\end{array}$ & & & & & $0.5 \mathrm{~mL}$ & $0.5 \mathrm{~mL}$ \\
\hline
\end{tabular}

acclimatized. Cholesterol measurements were carried out for each mouse on the $0,7^{\text {th }}$ and $15^{\text {th }}$ days after being fasted for 5 hours. The ration treatment is given orally galvalge (pipetted into the mouth) in the morning and evening, during the $1^{\text {st }}$ to $6^{\text {th }}$ day and the $8^{\text {th }}$ to the $14^{\text {th }}$ day. In the treatment of groups of mice were given egg yolks intermittently 1 hour after administration of the emulsion product. The group set up is in resemblance with previously conducted research. ${ }^{12}$ The individual consumption for each group is shown in Table 1.

Mice were monitored from the number of rations consumed, body temperature, and general observation every day, body weight, and $\%$-viability in each period of the 0 , $7^{\text {th }}$ and $15^{\text {th }}$ days. On the $15^{\text {th }}$ day surgery and retrieval of the kidneys and blood were carried out to test creatinine levels.

\section{Determination of Cholesterol Levels}

Cholesterol levels in the blood of each mouse were measured using the easy touch cholesterol test, after acclimatization for 7 days, i.e., on day 0. Subsequent measurements were made on days 7 and 15. Before taking blood, mice were fasted for 5 hours. ${ }^{13}$

\section{Determination of Creatinine}

The method used in measuring creatinine levels is Jaffe reaction. ${ }^{14}$ Reagent 1 (sodium hydroxide) $500 \mu \mathrm{L}$ was added to the sample (serum) mixed and incubated for 5 minutes. Then, Reagent II (picric acid) $500 \mu \mathrm{L}$ was added, mixed. The absorbance (A1) was read after 60 seconds and the second absorbance (A2) was read after 120 seconds to obtain the average absorbance $(\Delta \mathrm{abs})$. The absorbance reading used a spectrophotometer (BioSpectrometer, Eppendorf, Germany) with a wavelength of $510 \mathrm{~nm}$. The creatinine was calculated with following formula:

$$
\text { Creatinine }\left(\frac{\mathrm{mg}}{\mathrm{dL}}\right)=\frac{\Delta \text { Abs of sample }}{\Delta \text { Abs of standard }} \times \text { standard }\left(\frac{\mathrm{mg}}{\mathrm{dL}}\right)
$$

$\Delta$ Abs sample : delta absorbance 1 and 2 of sample $\Delta$ Abs standard : delta absorbance 1 and 2 of standard

\section{Determination of Kidney Weight and Volume}

Mice were anesthetized with diethyl ether, killed, and surgery was performed using asterile surgical instrument. The right and left kidneys were taken and cleaned from the sticking fat. Then, the kidney volume measurement was done through indirect measurements using a measuring cup. Then the weighing of the kidneys was carried out using an analytical balance.

\section{Results}

\section{Body Weight Changes and General Observations}

The average daily individual consumption per treatment group are shown in Table 2, meanwhile the changes in body weight of mice before and after treatment can be seen in Table 3. The standard ration given to mice per treatment group was $3 \mathrm{~g} \pm 5 \%$. From Table 2, the lowest average consumption was in the group of mice treated with egg yolk and $\beta$-carotene, namely $60.6 \pm 14.1 \%$ of the given ration. The highest consumption was in the group of mice with only $\beta$-carotene treatment, which was $91.3 \pm 5.6 \%$ of the given ration. 
Table 2. Average daily individual consumption per treatment group.

\begin{tabular}{|c|c|c|c|c|c|c|c|c|c|c|c|c|}
\hline \multirow{3}{*}{$\begin{array}{c}\text { Observation } \\
\text { Day }\end{array}$} & \multicolumn{12}{|c|}{ Average Daily Individual Cons umption per Treatment Group } \\
\hline & \multicolumn{2}{|c|}{1} & \multicolumn{2}{|c|}{2} & \multicolumn{2}{|c|}{3} & \multicolumn{2}{|c|}{4} & \multicolumn{2}{|c|}{5} & \multicolumn{2}{|c|}{6} \\
\hline & (g) & $(\%)$ & (g) & $(\%)$ & (g) & $(\%)$ & (g) & $(\%)$ & (g) & $(\%)$ & (g) & $(\%)$ \\
\hline 2 & 2.48 & 82.6 & 2.2 & 73.5 & 2.55 & 85.0 & 2.23 & 74.2 & 2.70 & 90.1 & 1.93 & 64.3 \\
\hline 3 & 2.75 & 91.8 & 2.24 & 74.8 & 2.71 & 90.3 & 1.86 & 62.1 & 2.84 & 94.7 & 1.69 & 56.3 \\
\hline 4 & 2.71 & 90.4 & 2.53 & 84.3 & 2.66 & 88.6 & 2.50 & 83.3 & 2.91 & 97.1 & 2.05 & 68.5 \\
\hline 5 & 2.68 & 89.5 & 2.45 & 81.5 & 2.75 & 91.7 & 1.74 & 58.1 & 3.01 & 100.2 & 2.29 & 76.2 \\
\hline 6 & 2.58 & 86.0 & 2.39 & 79.6 & 2.78 & 92.7 & 1.88 & 62.7 & 2.73 & 90.9 & 2.44 & 81.2 \\
\hline 7 & 2.66 & 88.7 & 2.23 & 74.3 & 2.62 & 87.2 & 1.71 & 57.1 & 2.80 & 93.5 & 2.42 & 80.7 \\
\hline 8 & 2.77 & 92.2 & 2.65 & 88.5 & 2.99 & 99.7 & 2.62 & 87.2 & 3.18 & 105.9 & 2.39 & 79.7 \\
\hline 9 & 2.70 & 90.1 & 2.12 & 70.8 & 3.09 & 103.1 & 1.55 & 51.7 & 2.97 & 98.9 & 2.01 & 66.9 \\
\hline 10 & 2.82 & 94.1 & 2.00 & 66.5 & 2.73 & 90.9 & 1.54 & 51.4 & 3.11 & 103.8 & 2.74 & 91.3 \\
\hline 11 & 2.83 & 94.2 & 2.41 & 80.5 & 2.51 & 83.7 & 1.62 & 53.9 & 2.82 & 94.0 & 2.44 & 81.3 \\
\hline 12 & 2.46 & 81.9 & 2.33 & 77.8 & 2.54 & 84.6 & 1.86 & 62.0 & 2.74 & 91.4 & 2.21 & 73.7 \\
\hline 13 & 2.54 & 84.7 & 2.14 & 71.2 & 2.87 & 95.7 & 1.69 & 56.2 & 2.51 & 83.8 & 2.28 & 76.1 \\
\hline 14 & 2.59 & 86.3 & 1.90 & 63.4 & 2.73 & 91.0 & 1.75 & 58.2 & 2.42 & 80.6 & 2.56 & 85.5 \\
\hline 15 & 2.46 & 82.0 & 2.24 & 74.8 & 2.82 & 93.9 & 0.91 & 30.3 & 1.40 & 46.7 & 3.03 & 101.1 \\
\hline Average & 2.65 & 88.2 & 2.27 & 75.8 & 2.74 & 91.3 & 1.82 & 60.6 & 2.73 & 90.8 & 2.32 & 77.3 \\
\hline Std Deviation & 0.13 & 4.3 & 0.20 & 6.8 & 0.17 & 5.6 & 0.42 & 14.1 & 0.43 & 14.5 & 0.34 & 11.4 \\
\hline
\end{tabular}

Overall, the average weight of mice treated with egg yolk experienced an average shrinkage of weight, which was from $25.43 \pm 4.60 \mathrm{~g}$ before treating it to $22.86 \pm 4.95 \mathrm{~g}$ on the $15^{\text {th }}$ day (Table 3 ).

Based on visual observations, all mice that received pure $\beta$-carotene intake experienced fur loss in the nape of the neck. It is also noted that in the treatment group $\beta$-carotene and egg yolk, mice tend to be aggressive indicated easy to bite and move actively (Table 4).

\section{Total Cholesterol Changes}

$\beta$-carotene given to mice lowered cholesterol by about $19.53 \pm 15.04 \%$ on the $7^{\text {th }}$ day. $\beta$-carotene and emulsion can overcome cholesterol increases up to day 7 (Table 5).

Table 3. Changes in body weight of mice with diets rich in $\beta$-carotene.

\begin{tabular}{lcccccc}
\hline \multirow{2}{*}{ Group } & \multicolumn{3}{c}{ Weight (g) } & & \multicolumn{2}{c}{ Weight Change (\%) } \\
\cline { 2 - 4 } \cline { 5 - 7 } & W0 & W7 & W15 & W7 - W0 & W15 - W7 \\
\hline Control & $26.37 \pm 4.13$ & $25.99 \pm 2.78$ & $26.27 \pm 3.17$ & & $-1.22 \% \pm 7.90 \%$ & $0.83 \% \pm 5.07 \%$ \\
Egg yolk & $25.43 \pm 4.60$ & $24.43 \pm 4.76$ & $22.86 \pm 4.95$ & & $-4.61 \% \pm 6.98 \%$ & $4.18 \% \pm 8.92 \%$ \\
$\beta$-carotene & $20.29 \pm 3.57$ & $22.29 \pm 2.66$ & $23.89 \pm 2.57$ & & $8.96 \% \pm 5.54 \%$ & $6.70 \% \pm 4.38 \%$ \\
$\beta$-carotene + Egg yolk & $26.76 \pm 2.77$ & $26.39 \pm 5.49$ & $21.02 \pm 1.48$ & & $-1.97 \% \pm 10.60 \%$ & $-32.78 \% \pm 50.45 \%$ \\
Emulsion & $27.90 \pm 1.51$ & $30.67 \pm 2.87$ & $28.79 \pm 1.91$ & & $8.75 \% \pm 3.97 \%$ & $-6.42 \% \pm 5.01 \%$ \\
Emulsion + Egg yolk & $25.96 \pm 4.46$ & $26.03 \pm 3.25$ & $25.77 \pm 1.99$ & & $0.54 \% \pm 9.47 \%$ & $-1.03 \% \pm 10.44 \%$ \\
\hline
\end{tabular}


Table 4. General observations of treatment groups.

\begin{tabular}{ll}
\multicolumn{1}{c}{ Treatment Group } & \multicolumn{1}{c}{ General Observation } \\
\hline Control & No abnormal activity and appearance is observed, body temperature is stable at \\
& $35.5 \pm 0.5^{\circ} \mathrm{C}$. \\
& Limp and inactiveare observed after the $7^{\text {th }}$ day, body temperature is stable at \\
& $35.5 \pm 0.5^{\circ} \mathrm{C}$. \\
Egg yolk & Weak and loss of furare observed after the $7^{\text {th }}$ day, there are mice which have \\
& cataract-like membranes in the eye, body temperature is stable at $35.5 \pm 0.5^{\circ} \mathrm{C}$. \\
$\beta$-carotene & Limp and dull fur are observed after the $7^{\text {th }}$ and $15^{\text {th }}$ days, body temperature is stable \\
& at $35.5 \pm 0.5^{\circ} \mathrm{C}$. \\
& No abnormal activity and appearance is observed, body temperature is stable at \\
Emulsion & $35.5 \pm 0.5^{\circ} \mathrm{C}$.
\end{tabular}

\section{Sob-chronic Toxicity}

Creatinine levels and kidney weight of mice were obtained after 15 days (Table 6). The group of mice treated with egg yolk had significantly different creatinine levels compared to the other treatment groups.

\section{Discussion}

\section{Body Weight Changes and General Observations}

Observations that need to be noted are that the average weight of mice in the treatment group of $\beta$-carotene is lower than other groups (Table 2 ). The $\beta$-carotene group had lower weight due to slight age difference of mice obtained from the breeder, so the comparison made is the difference in weight difference between the $7^{\text {th }}$ day after the treatment and the first day, and between the $15^{\text {th }}$ day and $7^{\text {th }}$ day.
Egg yolks are used as a food ingredient in a weight loss diet. $^{5}$ This is in line with the results of research on reducing weight as a result of a diet rich in fat. A higher reduction in weight was observed in mice treated with $\beta$-carotene and egg yolk at the $15^{\text {th }}$ day observation. Based on visual observations of mice in the treatment group $\beta$-carotene and egg yolk, mice tend to be aggressive indicated easy to bite and move actively, so that the weight decreases due to increased physical activity (Table 4). Several research explained that the consumption of carotene and zeaxanthin derived from corn caused an increase in the expression of several genes. ${ }^{15,16}$ The downstream effects that arise consist of changes in weight, energy and fat metabolism, regulation of apoptosis, and tumor suppression. In addition, consumption of these two active compounds also causes a decrease in gene expression of enzymes responsible for oxidative

Table 5. Changes in blood cholesterol of mice with diets rich in $\beta$-carotene.

\begin{tabular}{|c|c|c|c|c|c|}
\hline \multirow{2}{*}{ Group } & \multicolumn{3}{|c|}{ Cholesterol (mg/dL) } & \multicolumn{2}{|c|}{ Cholesterol Change (\%) } \\
\hline & Wo & W7 & W15 & W7 - W0 & W15 - W7 \\
\hline Control & $131.50 \pm 19.23$ & $151.25 \pm 21.00$ & $157.00 \pm 27.80$ & $13.06 \% \pm 8.15 \%$ & $3.66 \% \pm 32.10 \%$ \\
\hline Egg yolk & $136.00 \pm 20.18$ & $201.00 \pm 79.89$ & $244.50 \pm 185.97$ & $25.02 \% \pm 24.61 \%$ & $17.19 \% \pm 11.80 \%$ \\
\hline$\beta$-carotene & $136.00 \pm 19.71$ & $113.75 \pm 8.30$ & $192.50 \pm 78.56$ & $-19.53 \% \pm 15.04 \%$ & $35.96 \% \pm 16.31 \%$ \\
\hline$\beta$-carotene + Egg yolk & $149.25 \pm 33.33$ & $132.25 \pm 30.10$ & $154.50 \pm 23.33$ & $-18.98 \% \pm 45.62 \%$ & $18.20 \% \pm 24.71 \%$ \\
\hline Emulsion & $154.00 \pm 34.73$ & $146.25 \pm 19.21$ & $174.50 \pm 61.46$ & $-5.48 \% \pm 22.03 \%$ & $8.14 \% \pm 34.82 \%$ \\
\hline Emulsion + Egg yolk & $162.50 \pm 41.61$ & $123.00 \pm 9.42$ & $169.25 \pm 77.96$ & $-34.35 \% \pm 45.23 \%$ & $14.72 \% \pm 37.58 \%$ \\
\hline
\end{tabular}


Table 6. Changes in creatinine, renal weight and ratios of renal weight and body weight of mice with a diets rich in $\beta$-carotene.

\begin{tabular}{lcccc}
\hline \multicolumn{1}{c}{ Group } & $\begin{array}{c}\text { Creatinine } \\
(\mathbf{m g} / \mathbf{d L})\end{array}$ & $\begin{array}{c}\text { Renal Weight (KW) } \\
(\mathbf{g})\end{array}$ & $\begin{array}{c}\text { Weight Day-15 (W15) } \\
(\mathbf{g})\end{array}$ & $\begin{array}{c}\text { Ratio KW/W15 } \\
(\mathbf{g} / \mathbf{g})\end{array}$ \\
\hline Control & $0.650 \pm 0.574$ & $0.359 \pm 0.044$ & $26.270 \pm 3.166$ & $0.014 \pm 0.002$ \\
Egg-yolk & $2.100 \pm 0.707^{*}$ & $0.351 \pm 0.006$ & $22.860 \pm 4.950$ & $0.016 \pm 0.004$ \\
$\beta$-carotene & $0.300 \pm 0.115$ & $0.316 \pm 0.040$ & $23.885 \pm 2.565$ & $0.013 \pm 0.001$ \\
$\beta$-carotene + Egg yolk & $0.900 \pm 0.141$ & $0.306 \pm 0.009$ & $21.015 \pm 1.478$ & $0.015 \pm 0.001$ \\
Emulsion & $0.700 \pm 0.115$ & $0.350 \pm 0.017$ & $28.793 \pm 1.910$ & $0.012 \pm 0.001$ \\
Emulsion + Egg yolk & $0.600 \pm 0.283$ & $0.372 \pm 0.106$ & $25.770 \pm 1.989$ & $0.014 \pm 0.003$ \\
\hline
\end{tabular}

stress metabolism, unsaturated fat oxidation beta, pyruvate dehydrogenase complex, mitochondrial transporters, and prolongation of fatty acids. In particular, the significant impact that results from consuming $\beta$-carotene alone is changes in weight and energy metabolism.

A research group states that in several long-term studies, the effect is that $\beta$-carotene becomes a pro-oxidant agent, contrary to the assumption that $\beta$-carotene is an antioxidant. ${ }^{17}$ The dose holds the effect of changes in the function of $\beta$-carotene as an antioxidant or pro-oxidant. In the light of the previous research ${ }^{17}$, it can be deduced that inappropriate concentrations cause no protective effects found in mice.

The use of $\beta$-carotene-rich emulsions does not cause a decrease in the average weight of mice. Allegedly, the composition of the emulsion material which is quite complete (pumpkin, red palm oil, and dragon fruit) has an effect not only on the supply of pro-vitamin A, but also carbohydrates, fats and minerals which cause the weight of mice to not decrease. The composition of the active ingredients of the patented emulsion product is stable from the influence of the heating process carried out during the preparation of the emulsion product. ${ }^{18}$ It can be concluded that the consumption of emulsions does not cause changes in the weight of mice.

\section{Total Cholesterol Changes}

The use of test kits has been carried out in various similar studies. ${ }^{19,20}$ Mice that are kept tend to experience an increase in total cholesterol. Allegedly, the composition of hamsfood feed used contains fat species which triggers an increase in cholesterol. The fat content of hamsfood feed is $6 \%$. In another study, in ovariectomized mice, the use of supplements rich in $\beta$-carotene was able to overcome cholesterol increases and lipid peroxidation. ${ }^{21}$
Based on visual observations of mice in the $\beta$-carotene treatment group after the $7^{\text {th }}$ day, mice tended to experience behavioral changes, namely becoming more aggressive and hungrier faster, and there was loss of fur on the nape of the neck. Changes in the behavior of mice are thought to be related to an increase in certain body metabolism as an increase in lymphocyte activity was observed in parrotfish larvae. ${ }^{22}$ In some cases, brain activity increases due to consumption of $\beta$-carotene. ${ }^{23}$ Nape fur loss is an indication of hormonal changes in mice, including those caused by oxidative stress, low calorie diets, or certain micronutrient deficiencies. $^{24}$

The phenomenon of an increase in the average cholesterol level from mice occurred on the $15^{\text {th }}$ day due to the composition of hamsfood feed. Feeds are thought to be made with fats which easily increase total cholesterol levels. $\beta$-carotene protection against cholesterol changes does not occur after the $15^{\text {th }}$ day. The addition of $\beta$-carotene and emulsion treatments succeeded in lowering blood cholesterol in mice compared to mice treated with egg yolk alone. In aggregate, the treatment of $\beta$-carotene and emulsion is thought to be insufficient to overcome cholesterol changes on the $15^{\text {th }}$ day. It is suspected that mice metabolism changes, so that $\beta$-carotene and emulsion do not have a significant effect on cholesterol changes on the $15^{\text {th }}$ day. Consumption of $\beta$-carotene in a long duration does not provide real protection against cardiovascular disease or prolong life expectancy.$^{25}$ Similarly, consumption of $\beta$-carotene and vitamin $\mathrm{A}$ did not reduce the total serum cholesterol, HDL, and triglycerides from healthy communities. ${ }^{26}$ However, in groups experiencing oxidative stress, for example a group of workers exposed to asbestos, a decrease in serum $\beta$-carotene levels in the blood becomes a marker of the onset of cancer. ${ }^{24}$ 


\section{Sub-chronic Toxicity}

The sub-chronic toxicity of $\beta$-carotene depends on the origin of the extracted material. In this case, $\beta$-carotene derived from Yarrowia lipolytica has a value of no-observedadverse effect level (NOEL) of $500 \mathrm{mg} / \mathrm{kg}$ body weight. ${ }^{27} \mathrm{In}$ this study a dose of $0.2 \mathrm{mg} / \mathrm{kg}$ BW was used, much lower than the Grenfell-Lee study. ${ }^{27}$

Creatinine is used as an indicator of the health of kidney function, both in humans and in experimental animals. ${ }^{28}$ The metabolism of mice treated with egg yolk changes so that the average weight of mice tends to decrease. This metabolic change is indicated by an increase in creatinine levels, which is $2.100 \pm 0.707 \mathrm{mg} / \mathrm{dL}$ after 15 days of treatment. This is in line with the mathematical model built ${ }^{29}$, which states that an increase in creatinine levels was observed to occur linearly with the unit of time during which the test subjects consumed high protein foods, such as eggs. Additional treatment of $\beta$-carotene and emulsion successfully prevented increase in creatinine levels in mice given egg yolks. These results are in harmony with the phenomenon of antioxidant protective effects, such as $\beta$-carotene and vitamin $C$, against oxidative stress for patients with human kidney function deficiency ${ }^{30}$ and mice $^{31,32}$.

Kidney weight of all groups of mice was not significantly different. Visually, the kidneys did not appear to be swollen in all groups of mice. It can be concluded from creatinine data, kidney weight, and kidney visuals that the additional treatment of $\beta$-carotene and emulsion at the tested concentration does not cause sub-chronic poisoning for up to 15 days of treatment. Furthermore, consumption of carotenoids at recommended concentrations does not overload liver metabolism and kidney ${ }^{15}$, so that it can be concluded that up to the $15^{\text {th }}$ day observation, the emulsion products tested are safe.

\section{Conclusion}

The use of $\beta$-carotene-rich emulsions does not cause a decrease in the average weight of mice. In general, $\beta$-carotene and emulsion can overcome the increase in cholesterol on the $7^{\text {th }}$ day. The treatment of $\beta$-carotene and emulsion is thought to be insufficient to cope with cholesterol changes on the $15^{\text {th }}$ day as a result of standard consumption of hamsfood feed. The increase in creatinine levels was observed in mice treated with egg yolk control for up to 15 days of treatment. The additional treatment of $\beta$-carotene and emulsion successfully prevents the increase in creatinine levels. The addition of $\beta$-carotene and emulsion treatment at the tested concentration does not cause sub-chronic poisoning for up to 15 days of treatment.

\section{Acknowledgements}

The researchers thanked DRPM Ristekdikti for funding the research in the PUPT scheme of 2019.

\section{References}

1. Van der Made SM, Kelly ER, Berendschot TTJM, Kijlstra A, Lütjohann D, Plat J. Consuming a buttermilk drink containing lutein-enriched egg yolk daily for 1 year increased plasma lutein but did not affect serum lipid or lipoprotein concentrations in adults with early signs of age-related macular degeneration. J Nutr. 2014; 144(9): 1370-7.

2. Pisoschi AM, Pop A. The role of antioxidants in the chemistry of oxidative stress: a review. Eur J Med Chem. 2015; 97: 55-74.

3. Bohari B, Muhadir M, Rahmadi A. Vacuum evaporation and nitrogenassisted deodorization affects the antioxidant capacity in the olein fraction of red palm oil and its emulsion products. F1000 Res. 2018; 7: 1729. doi: 10.12688/f1000research.16545.1.

4. Saher G, Rudolphi F, Corthals K, Ruhwedel T, Schmidt KF, Löwel S, et al. Therapy of pelizaeus-merzbacher disease in mice by feeding a cholesterol-enriched diet. Nat Med. 2012; 18(7): 1130-5.

5. Blesso CN, Fernandez ML. Dietary cholesterol, serum lipids, and heart disease: are eggs working for or against you? Nutrients. 2018; 10(4): 426. doi: 10.3390/nu10040426.

6. Nishio N, Isobe K, Nishi H, Atsumi E, Asai H, Furusawa C. Do mice grow normally with an egg-only diet? Peer J Preprints. 2018; 6: e27000v1. doi: 10.7287/peerj.preprints.27000v1.

7. Andersen CJ. Bioactive egg components and inflammation. Nutrients. 2015; 7(9): 7889-913.

8. Harari A, Abecassis R, Relevi N, Levi Z, Ben-Amotz A, Kamari Y, et al. Prevention of atherosclerosis progression by 9 -cis- $\beta$-carotene rich alga dunaliella in apoE-deficient mice. BioMed Res Int. 2013; 2013: 169517. doi:10.1155/2013/169517.

9. Rahmadi A, Yanti I, Jannah SM, Rohmah M, Bohari, Supratman U. Quantitation and optimation of $\beta$-carotene and $\alpha$-tocopherol in emulsion prototype with reversed phase chromatography. IJASEIT. 2018; article in press.

10. Patel SS, Molnar MZ, Tayek JA, Ix JH, Noori N, Benner D, et al. Serum creatinine as a marker of muscle mass in chronic kidney disease: results of a cross-sectional study and review of literature. J Cachexia Sarcopenia Muscle. 2013; 4(1): 19-29.

11. Lailani M, Edward Z, Harman. Gambaran tekanan darah tikus wistar jantan dan betina setelah pemberian diet tinggi garam. Jurnal Kesehatan Andalas. 2013; 2(3): 146-50.

12. Lee WY, Lee R, Kim HC, Lee KH, Noh KS, Kim HW, et al. Consumption of water-soluble egg yolk extract on growth rate, changes in blood cholesterol levels, and immune modulation in BALB/c mice. Korean J Food Sci Anim Resour. 2013; 33(5): 587-94.

13. Jensen T, Kiersgaard M, Sørensen D, Mikkelsen L. Fasting of mice: a review. Lab Anim. 2013; 47(4): 225-40.

14. Delanghe JR, Speeckaert MM. Creatinine determination according to Jaffe_-what does it stand for? NDT Plus. 2011; 4(2): 83-6. 
15. Palczewski G, Airanthi M, Widjaja-Adhi K, Amengual J, Golczak M, von-Lintig J. Genetic dissection in a mouse model reveals interactions between carotenoids and lipid metabolism. J Lipid Res. 2016; 57(9): 1684-95.

16. Chen X, Chen YD, Boni GF, Liu X, Kuang J, Geng Z. Consuming egg yolk decreases body weight and increases serum HDL and brain expression of TrkB in male SD rats. J Sci Food Agric. 2019; 99(8): 3879-85.

17. Csepanyi E, Czompa A, Szabados-Furjesi P, Lekli I, Balla J, Balla $\mathrm{G}$, et al. The effects of long-term, low- and high-dose beta-carotene treatment in Zucker diabetic fatty rats: the role of HO-1. Int J Mol Sci. 2018; 19(4): 1132. doi: 10.3390/ijms19041132.

18. Vujasinovic V, Djilas S, Dimic E, Basic Z, Radocaj O. The effect of roasting on the chemical composition and oxidative stability of pumpkin oil. Eur J Lipid Sci Tech. 2012; 114(5): 568-574.

19. Gordon SM, Li H, Zhu X, Shah AS, Lu LJ, Davidson WS. A comparison of the mouse and human lipoproteome: suitability of the mouse model for studies of human lipoproteins. J Proteome Res. 2015; 14(6): 2686-95.

20. Fujimoto M, Tsuneyama K, Fujimoto T, Selmi C, Gershwin E, Shimada Y. Spirulina improves non-alcoholic steatohepatitis, visceral fat macrophage aggregation, and serum leptin in a mouse model of metabolic syndrome. Dig Liver Dis. 2012; 44(9): 767-74.

21. Nazıroğlu M, Cemil MG, GündüzalpÖ, Küçükayaz SM, Sözbir E. Apple cider vinegar modulates serum lipid profile, erythrocyte, kidney, and liver membrane oxidative stress in ovariectomized mice fed high cholesterol. J Membr Biol. 2014; 247(8): 667-73.

22. Anderson C, Jones R, Moscicki M, Clotfelter E, Earley RL. Seeing orange: breeding convict cichlids exhibit heightened aggression against more colorful intruders. Behav Ecol Sociobiol. 2016; 70(5): 647-57.

23. Crichton GE, Bryan J, Murphy KJ. Dietary antioxidants, cognitive function and dementia - a systematic review. Plant Food Hum Nutr. 2013; 68(3): 279-92.
24. Rajput RJ. Role of non androgenic factors in fur loss and fur regrowth. J Cosmo Trichol. 2017; 3(1): 118. doi: 10.4172/2471-9323.1000118

25. Hennekens CH, Buring JE, Manson JE, Stampfer M, Rosner B, Cook NR, et al. Lack of effect of long-term supplementation with beta carotene on the incidence of malignant neoplasms and cardiovascular disease. N Engl J Med. 1996; 334(18): 1145-9.

26. Redlich CA, Chung JS, Cullen MR, Blaner WS, Van-Bennekum AM, Berglund L. Effect of long-term beta-carotene and vitamin A on serum cholesterol and triglyceride levels among participants in the Carotene and Retinol Efficacy Trial (CARET). Atherosclerosis. 1999; 145(2): 425-32.

27. Grenfell-LeeD, Zeller S, Cardoso R, Pucaj K. The safety of $\beta$-carotene from Yarrowia lipolytica. Food Chem Toxicol. 2014; 65: 1-11. doi:10.1016/j.fct.2013.12.010

28. Gazdikova K, Gvozdjakova A, Kucharska J, Spustova V, Braunova Z, Dzurik R. Oxidative stress and plasma concentrations of coenzyme Q10, $\alpha$-tocopherol, and $\beta$-carotene in patients with a mild to moderate decrease of kidney function. Nephron. 2001; 88(3): 285. doi: $10.1159 / 000046007$.

29. Lykken GI, Jacob RA, Munoz JM, Sandstead HH. A mathematical model of creatine metabolism in normal males-comparison between theory and experiment. Am J Clin Nutr. 1980; 33(12): 2674-85.

30. Yu S, Pateau-Robinson I. Dietary supplements of vitamins $E$ and $C$ and $\beta$-carotene reduce oxidative stress in cats with renal insufficiency. Vet Res Commun. 2006; 30(4): 403-13.

31. Hosseini F, Naseri MKG, Badavi M, Ghaffari MA, Shahbazian H, Rashidi I. Protective effect of beta carotene pretreatment on renal ischemia/reperfusion injury in rat. Pakistan J Biol Sci. 2009; 12(16): 1140-5.

32. Hashim D, Gaughan D, Boffetta P, Lucchini RG. Baseline serum $\beta$-carotene concentration and mortality among long-term asbestosexposed insulators. Cancer Epidemiol Biomarkers Prev. 2015; 24(3): 555-60. 